\title{
The consequences of path dependency on funding for infill development in Victoria, Australia
}

\author{
Commonwealth Journal of Local Governance \\ Issue 20: December 2017 \\ http://cjlg.epress.lib.uts.edu.au
}

\section{Emily Killin}

Melbourne School of Design

The University of Melbourne

Australia

Email: emilykillin@gmail.com

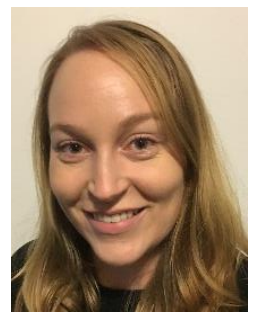

\section{Alan March \\ Melbourne School of Design \\ The University of Melbourne \\ Australia}

Email: alanpm@unimelb.edu.au

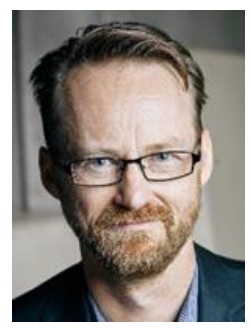

\begin{abstract}
The increasing responsibility of the local government sector to provide and maintain a range of infrastructure is threatening its financial sustainability. The 'development contributions' system is one measure adopted by local government in Victoria, Australia to assist in the funding of infrastructure required as a result of new development. The development contributions system is intended to be used state-wide, but in practice the majority of development contributions have been collected in just seven Melbourne municipalities associated with greenfield development. In July 2012 the Victorian state government announced reforms to the system, which were eventually enacted in October 2016. These reforms are considered in this paper. Using two case studies of Hume City Council and Surf Coast Shire Council, this paper assesses the effectiveness of the new funding system for infill development in the Melbourne area. The findings suggest that the historic path dependency of the system has resulted in a missed opportunity as the new system remains fundamentally designed for greenfield development rather than highly important infill development.
\end{abstract}

Keywords: Development contributions, infrastructure funding, infill development, Victoria.

\section{Introduction}

The collection of development contributions (DC) is a mechanism used in many countries to fund infrastructure required as a direct result of a development occurring. Elements funded may include roads, open space provisions, and community infrastructure. In the state of Victoria, Australia, the

DOI: http://dx.doi.org/cjlg.v0i20.6231

Article History: Received 31/07/2016; Accepted 04/06/2018; Published 18/08/2018

Citation: Commonwealth Journal of Local Governance 2017, 20:6231, http://dx.doi.org/cjlg.v0i20.6231

(C) 2018 Emily Killin and Alan March. This is an Open Access article distributed under the terms of the Creative Commons Attribution 4.0 Unported (CC BY 4.0) License (https://creativecommons.org/licenses/by/4.0/), allowing third parties to copy and redistribute the material in any medium or format and to remix, transform, and build upon the material for any purpose, even commercially, provided the original work is properly cited and states its license. 
system is referred to as the 'DC system', but other terms used include development levies, planning gains, planning obligations, extractions and impact feel. DC systems transfer part of the cost of infrastructure from the public to the private sector, and are used comprehensively in Australia, the United States and the United Kingdom (Cox 1991). DC systems are essentially:

A monetary contribution, or a contribution in kind through undertaking works, to the public sector by an individual involved in the land development conversion process. Such contributions are for the purpose of funding infrastructure, the need for which has arisen as a direct result of development taking place. Infrastructure refers to all physical services required to create a workable community with an acceptable standard of health, safety and amenity for all residents (SDCAC 2012, p. 13).

In Australia, the DC system was first introduced after the Second World War to fund infrastructure required to accompany the country's housing construction boom (Neutze 1995). A form of the system has been used in Victoria ever since, but has undergone a number of changes. In 1990 a landmark legal case known as the 'Eddie Barron decision' established the need for a clear set of principles for the DC system in Victoria. Prior to the Eddie Barron decision there was no specific statutory framework, and the DC system was generally imposed under planning permit conditions. The Eddie Barron case prompted change to the system's legislative framework, and in 1995 the DC system was legislated under the Victorian Planning and Environment Act 1987. The fundamentals of the changes made in 1995 are still used to collect DC in Victoria today (SDCAC 2012).

A comprehensive reform of Victoria's DC system was announced in 2011 in the document A New Victorian Local Government Contributions System - A preferred way forward (Victoria Department of Planning and Community Development 2012). In September 2012 the Minister for Planning appointed the Victorian Standard Development Contributions Advisory Committee (SDCAC) to review and report on the DC system. This led to an initial report prepared by the SDCAC in 2012 titled Report 1 - Setting the Framework. This committee's work eventually led to the passage of the Planning and Environment Amendment (Infrastructure Contributions) Bill 2015, which resulted in the new Infrastructure Contributions Plan (ICP) ${ }^{1}$ system for metropolitan greenfield growth areas in October 2016. The ICP system is yet to be available for regional growth areas and infill locations in the form of strategic development areas. In February 2018, the Planning and Environment Amendment (Public Land Contributions) Act 2018 received Royal Assent but is not yet in effect. This Act is a further reform and introduces a change to how land for public purpose is provided.

For the purpose of this paper the system outlined in Report 1 - Setting the Framework will be considered as the new DC system as this report broadly outlines the fundamentals of how the system has changed.

\footnotetext{
${ }^{1}$ The Infrastructure Contributions Plan (ICP) replaced the term Development Contributions Plan (DCP) via the Planning and Environment Amendment (Infrastructure Contributions) Bill 2015.
} 


\section{Methodology}

The paper's methodology consists of qualitative research in the form of document analysis and three semi-structured interviews. Two illustrative case studies, Hume City Council (HCC) and Surf Coast Shire Council (SCSC) were also examined.

A case study approach was chosen in this paper because case studies provide an authentic snapshot of current activity and behaviour. As Yin notes, within case studies "contemporary events are being examined and the relevant behaviors cannot be manipulated" $(2014$, p. 12). The essence of a case study is that it tries to illuminate a decision or set of decisions: why they were taken, how they were implemented, and with what result (Schramm and Stanford University 1971).

HCC was chosen as it only collected DC in a greenfield development setting, although it has areas undergoing urban renewal. SCSC was chosen as it collected DC in both greenfield and infill development settings.

Each case study analysed specific propositions, namely:

- In the case of SCSC, the components of the DC system which the council was able to use for infill development were sourced from the Torquay Jan Juc Development Contributions Plan (DCP) (SGS Economics and Planning 2011). The Torquay Jan Juc DCP was chosen because this document is specific to SCSC and details the infill infrastructure items implemented using the old DC system, enabling them to be analysed against the new DC system.

- In the case of HCC, the components of the DC system that inhibited its use for infill development were sourced from the barriers identified in Report 1 - Setting the Framework released in 2012 (SDCAC 2012); these were compared against the new DC system to understand if these barriers had been resolved.

Semi-structured interviews were conducted with employees from HCC and SCSC to further explore the findings from the case study analysis. One staff member from the strategic planning department at HCC, the Coordinator of Growth Area Planning (CGAP); and two SCSC staff, the Acting Manager of Strategic Planning (AMSP) and the Acting Coordinator of Strategic Planning (ACSP) were interviewed.

When Report 1 - Setting the Framework was released for public comment a total of 69 document submissions were received by the SDCAC, including submissions from councils, industry bodies and developers. The research analysed the submissions received in response to Report 1 - Setting the Framework to understand whether the reasons stated by SDCAC (2012) as to why the old DC system had not been utilised for infill development had been resolved by the new system. 


\section{Background to Victoria's DC system \\ Development contributions as a funding mechanism}

Infrastructure provision is generally understood to be extremely beneficial for a community (Beresford-Wylie et al. 2006). Transport infrastructure is required to allow citizens to access employment and facilities, deliver goods, and promote general health and well-being. A comprehensive provision of local infrastructure can make a location more sought after, enhancing land values (Gibbins 1990). Infrastructure is also required to meet community and social needs - one of Newman and Thornley's (1996) three functions of urban planning - the others being contribution to economic efficiency and protecting the environment.

Infrastructure provision is essential for a community to function, but its delivery is expensive and the best method of funding it is often debated. The planning historian and commentator Peter Hall argued that forward thinking and early investment in infrastructure is essential (Hall 2002). However, in Australia federal and state governments are often criticised for having a narrow economic focus and lack of long-term vision. The political drivers behind federal and state government decision-making often result in funding of large-scale infrastructure projects which are in the interests of a particular voter bloc, rather than the community as a whole. Smaller-scale infrastructure provision is of low priority to federal and state governments and has been passed on to local governments, often with little consideration as to the source of funding (Dollery et al. 2013).

This transfer of responsibility from higher to local governments is a relatively recent phenomenon. It can be observed that local government in Australia has moved away from the traditional definition of being responsible for 'roads', 'rates', and 'rubbish' and is taking on wider responsibilities (Dollery et al. 2013). This includes local government being involved in land use planning, engineering, community well-being, heritage conservation, tourism, economic development and building and property management (Beresford-Wylie et al. 2006). However, these additional responsibilities have come with limited or no financial assistance or consideration (Dollery and Crase 2006; Koutifaris and Mangioni 2012), resulting in increased financial pressures and a steady deterioration in the financial sustainability of the Australian local government sector (Dollery et al. 2013; Lopez et al. 2008; McNeill and Dollery 2000; Dollery and Mounter 2010). One of the most costly responsibilities is keeping up with the provision and maintenance of local infrastructure (Byrnes et al. 2008; Koutifaris and Mangioni 2012).

The problems of financial sustainability within Australia's local government sector were highlighted in a report by PriceWaterhouseCoopers (PWC) entitled National Financial Sustainability Study of Local Government (PWC 2006). ${ }^{2}$ The report suggests that across Australia, between $25 \%$ and $40 \%$ of

\footnotetext{
${ }^{2}$ A more recent robust empirical analysis of the financial sustainability of all Australian local governments does not exist; however, as identified by the more recent examples, this trend has continued.
} 
councils are financially unsustainable (p. 113). In Victoria specifically, according to this report AU \$203 million per annum is required for the local government sector to resolve its infrastructure backlog. This equates to a funding gap of AU\$2.6 million per Victorian council per annum (p. 113). In the 2016-17 audit of local government, the Victorian Auditor-General's Office (VAGO) ${ }^{3}$ concluded there was a declining trend in the financial sustainability of local governments when considering their responsibility to renew and maintain infrastructure assets (VAGO 2017). In New South Wales the situation is similar, with an independent review panel concluding the financial sustainability of councils has declined, with a significant number near crisis point (New South Wales Government 2013).

It would seem, therefore, that the current financial structure of local government is unsustainable. The increased scale and scope of local government spending and the decline in federal and state revenue streams is the principal factor behind this declining financial sustainability (Drew and Ryan, 2016). Therefore, the local government sector is increasingly required to pursue alternative funding mechanisms. Ratepayers generally resist the introduction of new taxes to fund infrastructure, especially if they foresee no benefit to themselves. Local governments are thus reliant on federal or state government grants, or revenue arising from prescriptive legislation. One example of such legislation is the DC system (Koutifaris and Mangioni 2012).

In Victoria, the Planning and Environment Act 1987 establishes the mechanism of collecting DC through the planning system. The new DC system introduces an Infrastructure Contributions Plan (ICP) (previously a Development Contributions Plan) as the document that outlines the infrastructure to be provided and the levies to be paid by individual developers as part of the land development process. The new DC system introduces a standard levy for specific infrastructure categories as the default in three development settings: growth areas, urban areas and strategic development areas. The standard levy will be applied per net developable hectare for growth areas or per dwelling for urban areas and strategic development sites. There is also an opportunity to apply a tailored levy which allows local governments to collect levies above those of the standard levy, if strategically justified.

\section{The benefits of infill development}

Under the old system, only $10 \%$ of the overall use of the DC system occurred in established settlement areas, which are those typically associated with infill development (SDCAC 2012). Yet infill development is an important principle outlined in the strategic planning document for Melbourne: Plan Melbourne (2017-2050) (Department of Environment, Land, Water and Planning 2017). This plan suggests that increasing densities around Melbourne's existing activity centres and public transport nodes is an important action to manage Melbourne's growth. Therefore, having a DC

\footnotetext{
3 The Victorian Auditor-General's Office (VAGO) plays a role in promoting confidence in the public sector by conducting audits to ensure public sector entities are transparent.
} 
system primed to fund infrastructure associated with infill development is both important and relevant.

Not only is there a push from the Victorian government for a greater focus on infill development, but there are a variety of benefits attributed to this development style in the literature, including benefits associated with 'greyfields'. For example, Newton (2010) argues that for cities to be more sustainable there needs to be a shift from urban sprawl to a greater focus on 'greyfield' development. Greyfields is a term describing:

the ageing, occupied residential tracts of suburbs which are physically, technologically and environmentally obsolescent and which represent economically outdated, failing or under-capitalized real estate assets. They usually occur in a 5-25km radius of the center of a city and are service, transport, amenity and employment rich compared to the outer and peri-urban suburbs (Newton 2010, p. 81).

The regeneration of greyfields has a range of benefits such as the generation of jobs, improvements to housing, neighborhood renewal, and environmental benefits (Tyler et al. 2013).

Greyfield development is beneficial as new residents can utilise existing infrastructure and services. However, increasing the population in these areas is likely to place strain on existing infrastructure. Capturing DCs associated with greyfield development would be beneficial, to provide funds to renew and update infrastructure to accommodate the growing population.

An alternative for accommodating Victoria's growth is urban sprawl; however, there are many negatives to urban sprawl discussed in the literature. Brueckner and Largey (2008) suggest lowdensity urban sprawl reduces social capital and therefore social interaction. Guettabi and Munasib (2014) make a connection between urban sprawl and a high body mass index in children. Pereira et al. (2014) suggest urban sprawl is negative when considering the environment, social factors, and economic factors: and specifically its effects on energy and water consumption, air and water pollution, human health problems, and soil and land consumption and degradation.

According to Newton and Glackin (2014), government policies are lacking to encourage infill development in Australian cities. Having an effective DC system to fund infrastructure associated with infill development could encourage a shift away from urban sprawl to renewing under-utilised existing suburbs.

\section{How the Victoria DC system works}

The DC system in Victoria is intended to be used state-wide, but to date approximately $90 \%$ of DCs have been collected in the seven Growth Area municipalities associated with greenfield development (SDCAC 2012). 
The theory of path dependency can be used to explain the limited use of the DC system in Victoria. This theory is defined by Bergek and Onufrey (2013, p. 1263) as "an accumulation of competences and activities into a persistent and stable pattern, driven by self-reinforcing processes that, in the absence of external shocks lead to an irreversible state of inflexibility". It can be applied to the use of the DC system in Victoria, because analysis indicates that DC funding principles generated by a famous legal case in 1990, the 'Eddie Barron' case, have governed the system ever since.

The Eddie Barron case - a dispute regarding a greenfield development - resulted in principles of 'need', 'nexus', 'equity' and 'accountability' being introduced to form the basis of the DC system in Victoria. These principles are defined by the Department of Transport Planning and Local Infrastructure (2007, pp. 12-13) as follows:

- Need - Infrastructure projects can be funded by DCs if they will be used by a future community. The need created by the development and the measures to satisfy the need must be adequately identified.

- Nexus - New development should not be considered on an individual basis, but as part of the wider community that will use the infrastructure. This may include existing development.

- Equity - The levy is calculated by sharing the cost of infrastructure amongst all likely users. This may include existing and future development.

- Accountability - The levies collected must be used to provide infrastructure specified in the DCP.

The principles of need and nexus are easier to apply in greenfield development settings than established areas as it is easier to argue that all the proposed infrastructure is required as a result of the new community and there is not an existing community that is required to contribute.

Although the DC system has undergone several changes, these principles remain the key metrics of the system outlined in Report 1 - Setting the Framework (SDCAC 2012).

\section{Study Findings}

The interviews confirmed that the theory of path dependency can usefully describe the formulation of the DC system in Victoria. For example, the Coordinator of Growth Area Planning at Hume City Council ('CGAP at HCC') stated:

The history of development contributions is an important consideration to think about. Development contributions evolved out of the Eddie Barron case. That was for a greenfield development out near Pakenham; therefore the whole basis of our DC system has been derived out of precedent setting arrangements that stemmed from that case (interview 15 July 2015). 
In order for a DC system to be implemented, the four principles cited above must be addressed. However, since these principles evolved out of greenfield considerations, they are difficult to apply in an infill development setting. This point was also made by the CGAP at HCC:

How appropriate is a system that has grown out of a greenfield site for infill development? We might not be looking at the right issues for an infill setting, if it's all fundamentally tied back to that case (interview, 15 July 2015).

The CGAP at HCC suggested that the new DC system has been somewhat adapted to an infill development setting, to the extent that the principle of 'equity' has been made easier to address. However, the other three principles remain tailored for greenfield settings:

There has been guidelines and small changes about how you make a better DC system but no one has really gone back to the fundamentals and suggested moving away from 'need', 'nexus', 'equity' and 'accountability'. Even the proposed changes have tried to maintain these principles as the foundation stone of the system, they've just tweaked certain elements on how you use it. For example, you still need to show 'need', 'nexus' and 'accountability'; they have just tweaked the 'equity' pillar a little bit. Therefore, it might be slightly easier to apply the proposed DC system to an infill development setting (interview, 15 July 2015).

\section{Factors inhibiting the use of the system for infill development}

The document analysis and the HCC case study analysis both considered the factors provided in Report 1 - Setting the Framework as to why the old DC system was not utilised in an infill development setting which are as follows:

- concern about demonstrating need and nexus

- concern about the need to specify infrastructure projects

- concern about unfunded liability

- concern about resources and expertise required to implement

- general view that the DCP system is not suited to infill

- concern about the effect on timing and rate of development

- lack of specific awareness of the incremental impact of infill development

- preference for more flexible 'Section 173 agreements'.

For the document analysis, submissions to the 2012 Report 1 - Setting the Framework were compared to the factors outlined above and summarised using two matrices. The two groups of submissions were analysed in matrices with one of the following responses recorded: Yes - the submission supports this factor; No - the submission does not support this factor; and, No mention - the submission does not mention this factor. The authors acknowledge that there are limitations to this approach, as the submitters were not specifically asked to consider the propositions identified in this paper prior to preparing their submission, and therefore they may have had opinions on propositions that were not captured. 
Submissions in response to Report 1 - Setting the Framework (SDCAC 2012) were reviewed to understand whether the replacement system eliminated the barriers preventing utilisation for infill development. To reflect this paper's focus only submissions made by local government in established areas and growth areas were included in the matrix summary $(\mathrm{N}=23)$. Document submissions from rural councils were excluded as they operate in a different development setting. The first category of submissions $(\mathrm{N}=16)$ was from councils in established areas, whose only form of development occurs in an infill setting (see Table 1).

Table 1: Summary of document analysis findings for established area councils

\begin{tabular}{|c|c|c|c|c|}
\hline \multicolumn{2}{|c|}{ Proposition } & $\begin{array}{c}\text { Response } \\
\text { 'Yes' }\end{array}$ & $\begin{array}{c}\text { Response } \\
\text { 'No' }\end{array}$ & $\begin{array}{c}\text { Response } \\
\text { 'No mention' }\end{array}$ \\
\hline \multicolumn{2}{|c|}{ Support the need for a reformed DC system } & 16 & 0 & 0 \\
\hline \multicolumn{5}{|c|}{ Propositions from Report 1 - Setting the Framework: } \\
\hline \multicolumn{2}{|c|}{ Concern about demonstrating 'need' and 'nexus' } & 3 & 4 & 9 \\
\hline \multicolumn{2}{|c|}{ Concern about the need to specify infrastructure projects } & 0 & 13 & 3 \\
\hline \multicolumn{2}{|c|}{ Concern about unfunded liability } & 5 & 8 & 3 \\
\hline \multicolumn{2}{|c|}{ Concern about resources and expertise required to implement } & 9 & 6 & 1 \\
\hline \multicolumn{2}{|c|}{ Concern about the effect on timing and rate of development } & 1 & 1 & 14 \\
\hline \multicolumn{2}{|c|}{ General view that the DCP system is not suited for infill } & 1 & 2 & 13 \\
\hline \multicolumn{2}{|c|}{ Preference for more flexible ' 173 agreements' } & 4 & 7 & 5 \\
\hline \multicolumn{2}{|c|}{ Total (Report 1 - Setting the Framework propositions) } & 22 & 41 & 48 \\
\hline Other relevant comments & \multicolumn{4}{|c|}{$\begin{array}{l}\text { Nine out of } 17 \text { established area councils supported the introduction of a } \\
\text { tailored levy for strategic development areas. Ten out of the } 17 \text { submissions } \\
\text { stated that the new system was biased towards greenfield development. }\end{array}$} \\
\hline
\end{tabular}

The second category of submissions $(\mathrm{N}=7)$ was from growth area councils, whose main type of development is greenfield development. These submissions were analysed firstly to determine whether infill growth was considered; and then, if it was, against the barriers highlighted by the SDCAC (Table 2).

Table 2: Summary of document analysis findings for growth area councils

\begin{tabular}{|c|c|c|c|c|}
\hline \multicolumn{2}{|c|}{ Proposition } & $\begin{array}{c}\text { Response } \\
\text { 'Yes' }\end{array}$ & $\begin{array}{l}\text { Response } \\
\text { 'No' }\end{array}$ & $\begin{array}{l}\text { Response } \\
\text { 'No mention' }\end{array}$ \\
\hline \multicolumn{2}{|c|}{ Support the need for a reformed DC system } & 7 & 0 & 0 \\
\hline \multicolumn{5}{|c|}{ Propositions from Report 1 - Setting the Framework: } \\
\hline \multicolumn{2}{|c|}{ Concern about demonstrating 'need' and 'nexus' } & 1 & 1 & 5 \\
\hline \multicolumn{2}{|c|}{ Concern about the need to specify infrastructure projects } & 0 & 2 & 5 \\
\hline \multicolumn{2}{|c|}{ Concern about unfunded liability } & 2 & 0 & 5 \\
\hline \multicolumn{2}{|c|}{ Concern about resources and expertise required to implement } & 0 & 1 & 6 \\
\hline \multicolumn{2}{|c|}{ Concern about the effect on timing and rate of development } & 1 & 0 & 6 \\
\hline \multicolumn{2}{|c|}{ General view that the DCP system is not suited for infill } & 0 & 1 & 6 \\
\hline \multicolumn{2}{|c|}{ Preference for more flexible '173 agreements' } & 0 & 0 & 7 \\
\hline \multicolumn{2}{|c|}{ Total (Report 1 - Setting the Framework propositions) } & 4 & 5 & 42 \\
\hline Other relevant comments & \multicolumn{4}{|c|}{$\begin{array}{l}\text { Five out of seven of the growth area councils did not mention the standard } \\
\text { levy for urban areas in their submission. Their submissions were entirely } \\
\text { centred on greenfield growth. The exception to this was the submissions put } \\
\text { forward by the City of Casey and Cardinia Shire Council. }\end{array}$} \\
\hline
\end{tabular}


The results in Table 1 and 2 show a large number of 'No Mention' responses, meaning the document analysis did not conclusively establish whether respondents believed the factors of concern would be addressed in the new system. However, Tables 1 and 2 still offer some useful insights into the effectiveness of the proposed DC system for infill development.

Nine out of 17 of the established area councils supported the introduction of a tailored levy for strategic redevelopment projects. However, ten out of the 17 submissions stated the new system was greenfield-development-focused, suggesting it might remain ineffective in infill development settings. Reasons for this view included:

- The proposed system did not consider upgrading existing infrastructure

- The levies were calculated per dwelling and should consider other users such as workers and visitors

- The tailored levy was only applicable to larger strategic development sites, and the new system did not offer flexibility for smaller strategic development sites

- The proposed 'allowable items'4 list for urban areas was much less comprehensive than for growth areas

- The high cost of land acquisition had not been factored in to the levy for established areas.

Among the growth area councils, five out of seven did not consider the standard levy for urban areas in their submission, as the submission was entirely greenfield-development-focused - suggesting that using the new DC system for infill development is not a priority for growth area councils. The exceptions were the City of Casey and Cardinia Shire Council, which remarked that the proposed standard levy for urban areas was a positive attribute of the new DC system.

The factors outlined in Report 1 - Setting the Framework were also considered in the Hume City Council (HCC) case study analysis. HCC is a Growth Area council located on Melbourne's northern fringe and spans an area of $504 \mathrm{~km}^{2}$. In 2016 the population of the municipality was 203,553 , and is expected to grow to 345,952 by 2036 (idcommunity 2017a). In the 2015/2016 financial year HCC received approximately AU\$22 million in DC levies. In 2017 there were seven DCPs approved in Hume.

The factors above were compared to the (then) existing and proposed DC systems. In the case of HCC, this analysis yielded an understanding of the features of the DC system which inhibit infill development and whether the new system would address these.

\footnotetext{
${ }^{4}$ The list of infrastructure that is able to be funded by the levy for each development setting (see SDCAC 2012).
} 
The same propositions were used in both the HCC case study and the document analysis. As discussed, the document analysis examined the submissions made in response to Report 1 - Setting the Framework. As the purpose of these submissions was not specifically to address the issues raised by SDCAC in 2012, this was secondary data collection. However, the HCC case study examined the same factors, with more conclusive results, and overall suggests that the new DC system for infill development is likely to be ineffective. A summary of the findings from the HCC case study are shown in Table 3.

Table 3: Summary of findings from Hume City Council case study

\begin{tabular}{|l|c|}
\hline \multicolumn{1}{|c|}{ Proposition } & $\begin{array}{c}\text { Would this issue be } \\
\text { resolved in the new system? }\end{array}$ \\
\hline Concern about demonstrating 'need' and 'nexus' & No \\
\hline Concern about the need to specify infrastructure projects & Partly \\
\hline Concern about unfunded liability & No \\
\hline Concern about resources and expertise required to implement & Yes \\
\hline General view that the DCP system is not suited to infill & Partly \\
\hline Concern about the effect on timing and rate of development & Not addressed by the new DC system \\
\hline Lack of specific awareness of incremental impact of infill development & Not addressed by the new DC system \\
\hline Preference for more flexible '173 agreements' &
\end{tabular}

Table 3 shows that the view of HCC was that, out of the propositions that could be addressed by the new DC system, one would be completely addressed, three would be partly addressed and two would not be addressed. A further two factors were deemed to be outside the scope of the DC system. On balance, therefore, it seems unlikely that the problems inhibiting the use of the DC system for infill development will be adequately addressed by the new system.

In conclusion, these findings suggest that Victoria's DC system is indeed path-dependent, and support Newton and Glackin's (2014) finding that government policies fail to encourage infill development in Australian cities.

\section{Benefits of the new system}

\section{Benefits of the standard levy for Urban Areas}

There were however some positive findings from the research. The main change in the new DC system is the introduction of standard levies for different development settings, including urban areas. Having a standard levy obviates discussion surrounding levy pricing - an often challenging and confusing process in established areas. This component of the new DC system updates the principle of 'equity'. The standard levy will alleviate the need to attribute the cost of infrastructure on a 'use' basis. 
The new DC system introduces a standard levy for urban areas, charged at a per-dwelling rate. The findings of this study suggest this is a positive change for infill development, as it makes it easier to address the DC principle of 'equity'. As the CGAP at HCC noted:

The equity pillar of the DC system has essentially been built into the new system, which makes it a lot more straightforward when considering infill development (interview, 15 July 2015).

But the other three principles of the DC system will remain difficult to address in infill developments, as they are not significantly changed by the new legislation, as the CGAP at HCC stated:

The current DC system is very hard to apply to an infill setting. The new system might make it a bit easier, but I'm not sure if easier is better. It could be great in one area but not great in another area (interview, 15 July 2015).

This study's findings suggest that the majority of established area councils support the introduction of a standard levy for infill development. However, they still have concerns about how the amount of the standard levy will be decided. A limitation of this paper is that, due to time constraints, it did not consider the SDCAC's Report 3 - Setting the Levies. Consideration of Report 3 - Setting the Levies (SDCAC 2013) could potentially alter the perception this thesis offers on the effectiveness of the standard levy for urban areas. If the levy is set too low, it may not be an attractive option for established area councils. This aspect of the issue merits further investigation.

\section{Benefits of the tailored levy for Strategic Development Sites}

In addition to the standard levy for different development settings, the new system introduces the option to apply for a tailored levy to collect levies above those of the standard levy, if strategically justified. While the tailored levy does not directly contribute to modernising the DC system, it is a positive attribute when considering strategic infill development sites. Accessing such a levy will require master planning of any potential infill development site, and detailed costing of the infrastructure required to underpin the development. It is to be hoped therefore that the introduction of this levy will encourage planning decisions in line with Peter Hall's 'big-picture', forward thinking planning approach mentioned above.

This form of master planning and visioning can be linked to Newman and Thornley's (1996) three functions of urban planning: meeting community and social needs, contributing to economic efficiency, and protecting the environment. Planning a site holistically, to include the required infrastructure and its funding from the outset, contributes to meeting community and social needs as well as economic efficiency. Furthermore, as discussed earlier in this paper, there are many benefits to developing underutilised 'greyfield' sites.

The ACSP at SCSC saw the introduction of a tailored levy for strategic development areas as a positive component of the new DC system. In SCSC's current DCP, the council has already split the 
site into small 'charging areas', which allows different levies to be clearly apportioned to different areas:

We used 26 small charging areas, which was a good way to set it out. It made deciding the levies a bit clearer, especially in relation to the nexus principle (interview, 31 August 2015).

The Acting Manager of Strategic Planning at SCSC further suggested that an advantage of the new system is that it makes the entire process simpler. One aspect of this is the scope to have a tailored levy for smaller development sites, instead of the current 'charging areas' (although these had been successful).

Additionally, the CGAP at HCC stated that the introduction of a tailored levy for strategic development areas could work well for a site with the potential for renewal, citing the example of HCC's Broadmeadows activity centre. This is an important activity centre close to public transport and other services. Its redevelopment is something HCC is considering as a future project. The CGAP stated:

The 'scatter-gun' approach to collecting DC is difficult: collecting some funds from a three-unit development here and some from another development there - you're only collecting a small amount and it can put a financial burden on councils. Having strategic development areas would work much better for infill, [and] this is something that is in the proposed changes. This could work well for Broadmeadows as a renewal site. The DCP could be applied to that particular site with a tailored levy (interview, 15 July 2015).

Having a DC system appropriate for infill development is extremely important for the sustainability of the local government sector moving forward. Overall, the introduction of the standard levy for urban areas and the option to tailor a levy to a strategic development area appears to be a step in the right direction for Victoria's DC system. The positive measures discussed above are increasing the likelihood that councils in established areas will use the DC system, which could potentially increase their financial sustainability.

Nevertheless, the proposed DC system remains designed for, and based on, a greenfield development setting, suggesting it is likely to remain difficult to apply it to infill development.

\section{Which activities will still be possible under the new system?}

Surf Coast Shire Council (SCSC) is located approximately $105 \mathrm{~km}$ south-west of Melbourne and spans an area of approximately $1,560 \mathrm{~km}^{2}$. The population of the municipality in 2016 was 29,839 , and is estimated to reach 45,717 by 2036 (idcommunity 2017b). The council received approximately AU\$3.5 million in DC levies for the 2016/2017 financial year from one approved DCP.

SCSC collects DC in both greenfield and infill development settings. The case studies seek to ascertain whether the components of the DC system associated with infill development in SCSC are 
present in the new system. The components are sourced from the Torquay Jan Juc DCP (SGS Economics and Planning 2011) and are as follows:

- Ability to fund infill infrastructure - roads

- Ability to fund infill infrastructure - community and indoor recreation

- Ability to find infill infrastructure - outdoor active and passive recreation

- Ability to fund infill infrastructure - on and off-road pathways (pedestrian/cycle).

The SCSC case study suggests that using the new DC system for infill development is feasible. In SCSC's current DCP there are 27 infrastructure projects intended to be part-funded by DC. These projects were mapped against the new DC system to test whether they will still be achievable. Table 4 summarises the results.

Table 4: Summary of findings from the Surf Coast Shire Council case study

\begin{tabular}{|c|c|c|}
\hline Proposition & What can be done in the new system & What can't be done in the new system \\
\hline $\begin{array}{l}\text { Ability to fund infill } \\
\text { infrastructure - } \\
\text { roads }\end{array}$ & $\begin{array}{l}\text { - Upgrade and signalise existing } \\
\text { intersection } \\
\text { - } \quad \text { Construct intersection } \\
\text { - } \quad \text { Construct roundabout }\end{array}$ & - Upgrade existing road \\
\hline $\begin{array}{l}\text { Ability to fund infill } \\
\text { infrastructure - } \\
\text { community and } \\
\text { indoor recreation }\end{array}$ & $\begin{array}{l}\text { - } \quad \text { Construct early learning centre } \\
\text { - } \quad \text { Construct arts/cultural centre } \\
\text { integrated with existing stadium } \\
\text { - } \quad \text { Construct community meeting space }\end{array}$ & $\begin{array}{l}\text { - Purchase land for early learning } \\
\text { centre } \\
\text { - } \quad \text { Purchase land for arts/cultural } \\
\text { space } \\
\text { - } \quad \text { Construct a stadium } \\
\text { - } \quad \text { Expand public library }\end{array}$ \\
\hline $\begin{array}{l}\text { Ability to fund infill } \\
\text { infrastructure - } \\
\text { outdoor active and } \\
\text { passive recreation }\end{array}$ & 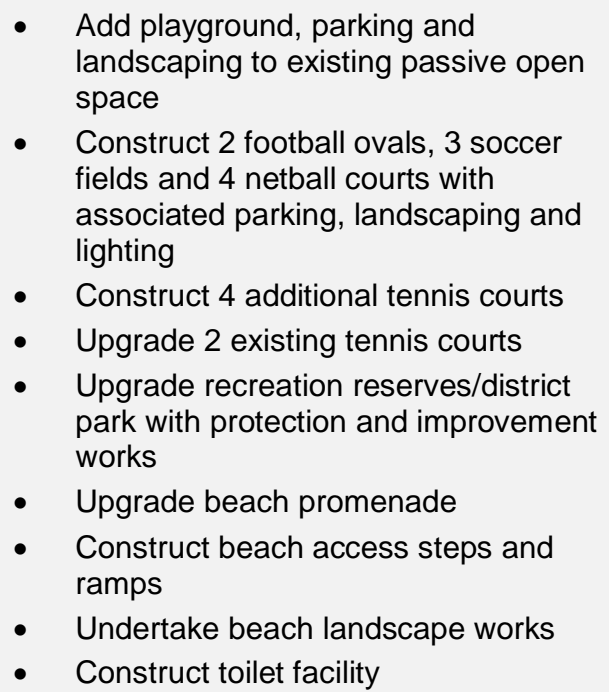 & $\begin{array}{l}\text { - } \quad \text { Construct sports pavilion } \\
\text { - } \quad \text { Develop recreation reserve }\end{array}$ \\
\hline $\begin{array}{l}\text { Ability to find infill } \\
\text { infrastructure - on- } \\
\text { and off-road } \\
\text { pathways } \\
\text { (pedestrian/cycle) }\end{array}$ & $\begin{array}{l}\text { - Construct pedestrian and cycle paths } \\
\text { through existing public open space } \\
\text { networks } \\
\text { - } \quad \text { Construct regional bike routes along } \\
\text { existing roads } \\
\text { - Construct shared path }\end{array}$ & $\begin{array}{l}\text { Construct regional park along } \\
\text { existing road }\end{array}$ \\
\hline
\end{tabular}


Of the 27 infrastructure projects, 18 were 'allowable items' in the new DC system, and nine were not. Therefore $67 \%$ of the infrastructure projects specified in SCSC's DCP could be implemented using the new DC system. The reason the nine projects could not be implemented was due to changes in the rules regarding allowable items. The SCSC case study therefore suggests that it is achievable to introduce a DCP in an infill development setting using the new system, and this was also the view of the Acting Manager of Strategic Planning at SCSC, who suggested the new system would make the development process much more straightforward for infill sites:

It would be much easier, much less complicated. The new system cuts out arguments in relation to the rate we charge, due to the introduction of the standard levy. It would be a case of 'go and argue with the state government, it's not a decision we made' (interview, 31 August 2015).

\section{Conclusion}

This paper has explored the effectiveness of the new DC system for infill development in Melbourne's Growth Areas. The authors suggest that its findings are likely to be applicable to other infill development settings across Melbourne as the new system is designed to be applicable across the state.

The authors find that the introduction of a standard levy for urban areas and the option of applying for a tailored levy for strategic development sites are positive aspects of the new DC system when considering its use for infill development. However, the barriers to using the DC system for infill projects cited by the SDCAC in 2012 appear to remain, suggesting it is still a system primarily suited to greenfield development. This was also the view of ten out of the 17 established area councils examined.

The authors conclude that the new DC system is still ineffective for infill development. The 'Eddie Barron' principles of 'need', 'nexus', 'equity' and 'accountability' which govern DC were developed over 20 years ago, based on a dispute regarding a permit condition on a greenfield development - yet, apart from the 'equity' principle, they have not been re-examined in the new Act to update them and ensure they are suitable for all types of development. This is a clear example of path dependency.

On a positive note, however, the principle of 'equity' has been re-worked, making it easier to address for infill development.

The introduction of a tailored levy for strategic development sites will also make applying the DC system to infill development more straightforward, and should encourage forward thinking and early investment in infrastructure. However, this is only a small step towards addressing Newton's concern that more greyfield development is needed (2010), and further reform may be necessary before Victoria's infill sites can fulfil their true potential. 


\section{Declaration of conflicting interest}

The authors declared no potential conflicts of interest with respect to the research, authorship, and/or publication of this article.

\section{Funding}

The authors received no financial support for the research, authorship, and/or publication of this article.

\section{References}

Beresford-Wylie, A., Watts, G. and Thurairaja, V. (2006) Financing local government infrastructure: The Australian experience. Sustaining Regions, 5 (2), 5-15.

Bergek, A. and Onufrey, K. (2013) Is one path enough? Multiple paths and path interaction as an extension of path dependency theory. Industrial and Corporate Change, 23 (5), 1261-1297. https://doi.org/10.1093/icc/dtt040

Brueckner, J.K. and Largey, A.G. (2008) Social interaction and urban sprawl. Journal of Urban Economics, 64 (1), 18-34. https://doi.org/10.1016/j.jue.2007.08.002

Byrnes, J., Dollery, B., Crase, L. and Simmons, P. (2008) Resolving the infrastructure funding crisis in Australian local government: A bond market issue approach based on local council income. Australasian Journal of Regional Studies, 14 (2), 115-131.

Cox, G. (1991) Financing of urban public infrastructure from developer contributions: A review of New South Wales and United States practice. Sydney: Planning Research Centre, University of Sydney.

Department of Environment, Land, Water and Planning. (2017) Plan Melbourne (2017-2050). Victoria, Australia: Victorian Government.

Department of Planning and Community Development. (2012) A new Victorian local development contribution system. Victoria, Australia: Victorian Government.

Department of Transport Planning and Local Infrastructure. (2007) Development contributions guidelines. Victoria, Australia: Victorian Government.

Dollery, B. and Crase, L. (2006) Australian local government economics. Sydney: UNSW Press. https://doi.org/10.1111/j.1467-8500.2007.00550_9.x

Dollery, B., Kortt, M.A. and Grant, B. (2013) Funding the future: Financial sustainability and infrastructure finance in Australian local government. Annandale, NS: Federation Press.

Dollery, B. and Mounter, S. (2010) Local infrastructure investment, maintenance and renewal: A comparative analysis of contemporary Australian and New Zealand local government. Australasian Journal of Regional Studies, 16 (2), 217-232.

Drew, J. and Ryan, R. (2016) Improving the financial sustainability of local governments. Sydney, Australia: The University of Technology Sydney McKell Institute.

Gibbins, R. (1990) Developer contributions and infrastructure funding. Urban Policy \& Research, 8 (4), 197202. https://doi.org/10.1080/08111149008551447

Guettabi, M. and Munasib, A. (2014) Urban sprawl, obesogenic environment, and child weight. Journal of Regional Science, 54 (3), 378-401. https://doi.org/10.1111/jors.12123

Hall, P.G. (2002) Cities of tomorrow: An intellectual history of urban planning and design in the twentieth century. Malden, MA: Blackwell Publishers. 3rd ed. https://doi.org/10.1016/0264-2751(90)90075-i

idcommunity. (2017a) Hume City Council population forecast. Available at : http://forecast.id.com.au/hume/home [Accessed 25 May 2018].

idcommunity. (2017b) Surf Coast Shire community profile. Available at: http://profile.id.com.au/surfcoast/home [Accessed 25 May 2018]. 
Koutifaris, K. and Mangioni, V. (2012) Rates versus developer contributions as revenue sources for local government. Commonwealth Journal of Local Governance, (11), 53-74. https://doi.org/10.5130/cjlg.v0i0.3057

Lopez, M., Dollery, B. and Byrnes, J. (2008) Financing sustainability in local government: An analysis of the roads to recovery program in New South Wales local government. Public Policy, 3 (2), 141-158.

McNeill, J. and Dollery, B. (2000) Funding urban infrastructure using developer charges: The case of Section 94 contributions and road financing in New South Wales. Public Works Management \& Policy, 4 (4), 297304. https://doi.org/10.1177/1087724x0044004

Neutze, M. (1995) Financing urban services. In: Troy, P. (ed.) Australian cities: Issues, strategies and policies for urban Australia in the 1990s. (pp. 220-246). Melbourne: Cambridge University Press. https://doi.org/10.1017/cbo9780511597183.012

Newman, P. and Thornley, A. (1996) Urban planning in Europe: International competition, national systems, and planning projects, London; New York: Routledge. https://doi.org/10.4324/9780203427941

Newton, P. and Glackin, S. (2014) Understanding infill: Towards new policy and practice for urban regeneration in the established suburbs of Australia's cities. Urban Policy \& Research, 32 (2), 121-143. https://doi.org/10.1080/08111146.2013.877389

Newton, P.W. (2010) Beyond greenfield and brownfield: The challenge of regenerating Australia's greyfield suburbs. Built Environment, 36 (1), 81-104. https://doi.org/10.2148/benv.36.1.81

New South Wales Government, Independent Local Government Review Panel. (2013) Revitalising local government: Final report of the NSW Independent Local Government Review Panel. Sydney: New South Wales Government.

Pereira, P., Monkevicius, A. and Siarova, H. (2014) Public perception of environmental social and economic impacts of urban sprawl in Vilnius. Societal Studies, 6 (2), 259-290. https://doi.org/10.13165/sms-14-62-03

PriceWaterhouseCoopers. (2006) National financial sustainability study of local government. New South Wales, Australia: PriceWaterhouseCoopers.

Schramm, W. and Stanford University. (1971) Notes on case studies of instructional media projects. Stanford, California: Stanford University California Institute for Communication Research.

Standard Development Contributions Advisory Committee. (2012) Report 1 - setting the framework. Victoria, Australia: SDCAC.

Standard Development Contributions Advisory Committee. (2013) Report 2 - setting the levies. Victoria, Australia: SDCAC.

SGS Economics and Planning. (2011) Torquay Jan Juc development contributions plan. Victoria, Australia: SGS Economics and Planning.

Tyler, P., Warnock, C., Provins, A. and Lanz, B. (2013) Valuing the benefits of urban regeneration. Urban Studies, 50 (1), 169-190. https://doi.org/10.1177/0042098012452321

Victorian Auditor-General's Office. (2017) Results of the 2016-17 audits: Local government. Victoria, Australia: Victorian Government.

Victorian Government. (1987) Planning and Environment Act 1987. Victoria, Australia: Victorian Government.

Yin, R.K. (2014) Case study research: Design and methods. Los Angeles: SAGE. https://doi.org/10.3138/cjpe.30.1.108 